\title{
Biblical Rhetoric
}

\section{As Illustrated by Judah's Speech in Genesis 44:18-34 \\ Jan Joosten, Christ Church, OX1 1DP Oxford}

Persuasive speech takes an important place in the Hebrew Bible. It is, alongside narrative and poetry, one of the principal genres of biblical texts. The lion's share of the prophetical books, much of wisdom literature, and the bulk of the biblical law codes belong to this category. In addition, most of the speeches inserted into the historical books are rhetorical in nature. ${ }^{1}$ Rhetorical units range from the very brief, such as Bathsheba's speech in $1 \mathrm{Kgs}$ 1:17-21, in which she tries to persuade David to name Solomon as his successor, to the very long, such as Moses' oration in Deut 1-30, in which he transmits the divine laws to the Israelites before they occupy the promised land. The objective of speeches varies: Abigail attempts to save the life of her husband (1 Sam 25:25-31); Jotham son of Gideon intends publicly to blame the citizens of Shechem for killing his seventy brothers (Jud 9:7-20); the teacher of wisdom in Prov 1-9 seeks to turn away his disciple from nefarious influences and to lead him into the way of success; as to God, answering Job from the whirlwind, his objective seems to be to demonstrate that he can be just and omnipotent all at once (Job 38-40). Anyone can make a speech: the king, a prophet, or a private person, highborn or low; man, woman or child; and indeed God himself. The audiences too represent many different walks of life. The biblical authors, it seems, delight in staging various sorts of oratory. Yet across all this variety, the persuasive quality remains constant: the goal of all these speeches is to convince.

In light of the undoubted importance of this literary genre, it is striking to observe that no method has been developed to approach biblical oratory as such. The term "rhetoric" is often encountered in biblical studies, but usually what is meant is simply matters of style. Eduard König's classic, called "Stylistics, Rhetoric, Poetics"-Stilistik, Rhetorik, Poetik in bezug auf die biblische Literatur komparativisch dargestellt - ${ }^{2}$ is almost entirely taken up with the analysis of stylistic features. More recent work, by Alonso Schökel and others, does

\footnotetext{
${ }^{1}$ A theoretical distinction is to be maintained between real discourse and speeches recreated in a literary work. Nevertheless, as will be further discussed below, the two genres share some important characteristics and should not be forced too far apart. See below note 13.

${ }^{2}$ E. König, Stilistik, Rhetorik, Poetik in bezug auf die biblische Literatur komparativisch dargestellt (Leipzig: Dieterich, 1900).
} 
not radically depart from this approach. ${ }^{3}$ Again, the last 35 years or so have seen the development of a method called "rhetorical criticism". The method innovates in that it pays attention to the structure of biblical texts. Particularly prominent are "chiastic" or "palindromic" structures of the type A $-\mathrm{B}-\mathrm{C}-\mathrm{X}-\mathrm{C}$ ' $-\mathrm{B}$ ' $-\mathrm{A}$ ', discovered in a very great variety of passages including narrative and poetry. ${ }^{5}$ This hardly amounts to a global theory of biblical rhetoric, however.

Rhetoric in the narrow sense of the word, the exercise of speech for persuasion, is not defined by style or structure alone. What distinguishes persuasive speech from all other literary genres is its relation to the speech situation. Rhetoric, in contradistinction to narrative or poetry, is "speech in action". Stories, including historical narrative, transport the audience to a period not directly connected to the time of the speaker and his or her audience; ${ }^{6}$ poetry creates a world of its own. ${ }^{7}$ But persuasive speech is entirely directed toward influencing the situation in which it takes place. The proverb that says: "Death and life are in the power of the tongue" (Prov 18:21) refers to persuasive speech, in a court of justice, say, or in a deliberative assembly. The essence of oratory is not situated in the discourse, but in reality. An example will illustrate this. After Elijah, according to the story in $2 \mathrm{Kgs} \mathrm{1}$, has brought down fire from heaven on two officers with their fifty soldiers, a third officer is sent to bring him to King Ahaziah. Unlike the first two, the third officer does not simply order the prophet to go see the king ("Man of God, the king says: Come down"), but pronounces a short speech:

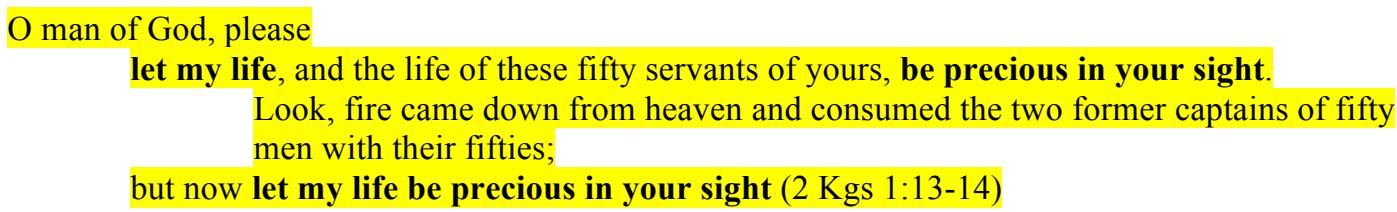

\footnotetext{
${ }^{3}$ See, e.g., J. Muilenburg, 'Form Criticism and Beyond', JBL 88 (1969), 1-18; B. W. Anderson, 'The New Frontier of Rhetorical Criticism', in J.J. Jackson and M.J. Kessler (eds.), Rhetorical Criticism (Pittsburgh 1974), ix-xviii; I.M. Kikawada, 'Some Proposals for the Definition of Rhetorical Criticism', Semitics 7 (1977), 67-91; M.J. Kessler, Art and Meaning: Rhetoric in Biblical Literature (JSOTSup 19; Sheffield: XXX, 1982); L. Alonso Schökel, A Manual of Hebrew Poetics (SubBi 11; Rome: PIB, 1988).

${ }^{4}$ See, e.g. D.F. Watson, A.J. Hauser, Rhetorical Criticism of the Bible. A Comprehensive Bibliography with Notes on History and Method (Biblical Interpretation Series 4; Leiden: Brill, 1994).

${ }^{5}$ See e.g. R. Meynet, Treatise on Biblical Rhetoric (Leiden: Brill, 2012).

${ }^{6}$ For the distinction between narrative and "discursive" texts, see in detail H. Weinrich, Tempus - Besprochene und erzählte Welt (1964 and many subsequent editions).

${ }^{7}$ For this definition of poetry, see the seminal thoughts in R. Jakobson, 'Closing Statement: Linguistics and Poetics', in T. A. Sebeok, Style In Language (Cambridge MA: MIT, 1960), 350-377, in particular 356-357.
} 
The words of the captain of fifty exhibit a nice style ("let my life be precious in your sight", "these servants of yours"), and an elegant inclusio. Nevertheless, it is plain to see that the essence of the speech is not situated in the style or the structure. The oratorical art of the officer is entirely oriented toward a practical goal, namely, to obtain from the prophet that he should come to the King. This point is not mentioned in the speech. Ostensibly, what the officer asks from the prophet is to let him live. But what is at issue is Elijah's readiness to appear before the king. Elijah understands this, and according to the story accepts to go with the captain.

Rhetoric acts on what linguists call the "pragmatic context", and draws from it its force. It is impossible to understand this type of speech without taking account of the situation within which it is pronounced. No method has been developed to approach biblical oratory in light of this quality. The essence of biblical poetry has been investigated since Robert Lowth's Lectures on the Sacred Poetry of the Hebrews. Penetrating monographs by Meir Sternberg, Robert Alter and several others have illuminated the inner workings of Biblical narrative. ${ }^{8}$ But nothing similar exists for biblical rhetoric. ${ }^{9}$

There is, however, a body of knowledge that can be helpful in developing such a method, namely, classical rhetoric. ${ }^{10}$ In the classical world, in Greece and in Rome, handbooks were composed explaining how to produce a successful oration. Centuries of intense study led to the elaboration of a global and unified theory of persuasive speech. In the classical theory, rhetoric was from the start conceived of as "speech in action". The classical authors-Aristotle, Quintilian, Cicero, and many others - understood that the crucial concerns of a speech lie not within the discourse, but without it, in reality. Thus, classical rhetoric

\footnotetext{
${ }^{8}$ R. Alter, The Art of Biblical Narrative (Harper Collins, 1981); M. Sternberg, The Poetics of Biblical Narrative. Ideological Literature and the Drama of Reading (Bloomington: Indiana University, 1987).

${ }^{9}$ Highly suggestive hints have been proposed by the doyen of specialists of classical rhetoric: see George
} A. Kennedy, 'Old Testament Rhetoric', in idem, Classical Rhetoric and its Christian and Secular Tradition from Ancient to Modern Times (Chapel Hill: University of North Carolina Press, 1980), 120-125; idem, 'Rhetoric in the Biblical Book of Proverbs' and 'Persuasion in the Old Testament', in idem, Comparative Rhetoric. An Historical and Cross-Cultural Introduction (New York \& Oxford: OUP, 1998), 133-137.

${ }^{10}$ Works on classical rhetoric are numerous. See, e.g., Heinrich Lausberg, Handbook of Literary Rhetoric. A Foundation for Literary Study (Leiden: Brill, 1998); G. A. Kennedy, Classical Rhetoric and Its Christian and Secular Tradition (1980 and many subsequent editions); S. Porter, (ed.) A Handbook of Classical Rhetoric (Leiden: Brill, 1997). A very penetrating presentation, with many hints regarding the relevance of classical notions for the analysis of literary texts, is fond in R. Barthes, ' $L$ 'ancienne rhétorique. Aidemémoire', in idem, L'aventure sémiologique (Paris: Seuil, 1985), 85-165. 
develops the notion of "ethos": the capacity of orators to project of themselves the image of someone who is wise, just, and likeable; it develops the notion of "pathos": the capacity to awaken the feelings of the audience and to harness them to the persuasive enterprise. Classical rhetoric underscores the value of "non-artistic arguments" (pisteis atechnoi): persuasion may be based on the use of elements taken from real life, facts, opinions, even concrete objects. Above all, classical rhetoric develops the central notion of stasis: the question at issue, the point on which the orator wants to convince the audience. Classical rhetoric does not neglect the discourse: it has things to say on style (elocutio), on structure (dispositio) and on the logical flow of argument (logos). However, these discursive means of persuasion remain subordinate to the extra-linguistic objective. What matters is not what is said, but how this affects the real world.

If we want to apply insights of classical rhetoric to biblical texts, we should of course pay heed to linguistic and cultural differences between the classical and the biblical worlds. We should not attempt to press the biblical data into a classical straightjacket. Nonetheless, the systematic analysis of the means of persuasion proposed in the classical sources may be expected to throw light on biblical rhetoric. The use of speech to obtain results in the real world is not limited to ancient Greece and Rome: it is universally human. ${ }^{11}$

In light of these considerations, a number of observations will be proposed on one of the most gripping speeches contained in the Old Testament: the speech that Judah addresses to a minister of Pharaoh after Benjamin, his younger brother, has been accused of stealing the minister's silver cup. ${ }^{12}$ Of course, the words we read in Genesis 44:18-34 are not the transcript of a real address. The speech is imaginary, the artistic product of the author of the Joseph story. Even if it is not a real speech, however, we may expect it to be similar to a real speech. If Judah didn't express himself in this way, someone like him could have expressed himself in this way if he had found himself in the situation presupposed in the story. In general it may be said that the speeches incorporated into the biblical narrations, although they are not real, are realistic. They imitate true speech. The author of Judah's speech deploys

\footnotetext{
${ }^{11}$ Another important matter is that classical rhetoric is in principle prescriptive, it defines how one can produce a persuasive speech. This characteristic sets classical rhetoric apart from the scholarly approach, which is descriptive in nature.

12 In addition to the commentaries, see Y. Gitay, 'The role of rhetoric in the rise of leadership: The case of Judah', Journal of Semitics 14/1 (2005), 112-148; P. Weimar, 'Eine bewegende Rede: Komposition und Theologie der Rede Judas in Gen 44,18-34', in idem, Das Manna fällt auch Heute noch: Beiträge zur Geschichte und Theologie des Alten, Ersten Testaments (Freiburg: Herder, 2004), 638-659.
} 
techniques that an Israelite of the biblical period could have used. The audience are supposed to be able to relate to the heroes of the narrative, who are represented as their own ancestors. ${ }^{13}$

Apart from artistically created speeches inserted into the narrative, such as the one we will consider presently, the Hebrew Bible contains, arguably, the transcript of real speeches in the prophetical books. ${ }^{14}$ In a sense it would be more logical to start the study of biblical rhetoric with prophetic speeches-more logical, but less expedient. The great advantage of the imaginary speeches is that they are presented within a narrative framework permitting to reconstruct their "pragmatic contexts": as readers of the story, we know why Judah decides to speak to the Egyptian minister; and if we are attentive we can find out what Judah tries to achieve. This is precious information. Speeches recorded in the prophetical books often come without any indication as to the real circumstances in which they were originally pronounced. Lack of information on the historical context makes it very difficult to understand many prophetic oracles, or even completely impossible. ${ }^{15}$

\section{Analysis of Judah's speech according to classical rhetoric}

When the silver cup is found in Benjamin's sack, it appears the younger brother has been caught red-handed. Although the reader knows Benjamin did not steal the cup, the brothers have to admit his apparent guilt. The minister-who is none other than Joseph, although the brothers do not know this ${ }^{16}$ - pronounces his judgment: Benjamin will be his slave, the others are free. What can the brothers say? They are foreigners in a land not their own. The facts speak against them. And the minister is at once the accuser, the judge, and the wronged party!

\footnotetext{
${ }^{13}$ The reality constructed in narrative is different from the reality of the reader, but the difference between the two should not be exaggerated. The reality one inhabit is only accessible through mental representation and, indeed through language and narrative. Readers relate to the fictional reality constructed in narrative as a mental representation comparable to the mental representation they make of their own "real" reality.

${ }^{14}$ The relation of the prophecies contained in the prophetic books and the actual words of the prophets is of course a delicate matter. Some of the literary units included in the books may from the start have been composed in writing, while other units may have undergone heavy and complex redaction between their oral performance and the written form that has come down to us. For further discussion of this problem, see J. Joosten, 'Prophetic discourse and popular rhetoric in the Hebrew Bible', Canon \& Culture 7 (2013), 4358.

${ }^{15}$ See on this point Joosten, 'Prophetic discourse', 55-56.

${ }^{16}$ In traditional Jewish interpretation it is often supposed that the brothers do know the identity of the minister, but this is contrary to what is stated expressly in Gen 42:8, 23.
} 
Even so, Judah will try to defend his little brother. He has pledged his own life for him to his father, and now he will do all he can to bring him back home. From a position of extreme weakness, Judah calls up the only strength he has: that of speech.

Classical rhetoric prescribes three distinct steps in the production of a successful speech: finding the right arguments, arranging them in an efficient way, and elaborating the style. All three steps flow from the stasis, the definition of the point at issue.

\section{Stasis and inventio}

The point at issue for Judah is to obtain from the minister that Benjamin should be allowed to go home. His speech is judicial in nature, but of a very specific genre. The objective cannot be to show that Benjamin is innocent, nor to invoke mitigating circumstances. ${ }^{17}$ Both these strategies would be without hope. Instead Judah chooses the one line of argument that is open to him: he pleads what we would call the clemency of the court. He bases his request to liberate Benjamin, and to take him himself in his place as slave, not on Benjamin's innocence, nor on the fact that he is a minor, but exclusively on the goodness of the judge's heart.

In line with the strategy he has selected, Judah chooses his arguments particularly in the area of what is called pathos in classical rhetoric: the manipulation of the feelings of his audience. Judah repeats several times that their father is old; that Benjamin is a young boy; some catastrophe already happened in the family: these details are designed to arouse the compassion of the minister. When Judah speaks of their earlier visit of the brothers, he takes care to present it as a pleasant encounter: "My lord asked us: Do you have a father, or a brother... (v. 19) And you said: Bring him down to me that I may set my eye on him (v. 21)." In creating this picture of the earlier visit, Judah tries to return the minister to a similarly solicitous et of mind.

Admittedly, Judah has some other arguments, such as his vow to his father to bring Benjamin back to him. But the additional arguments hardly lay any weight in the scales.

\section{Dispositio}

In classical rhetoric, a judicial speech should have four parts: an introduction (exordium), a narration of the facts (narratio), a demonstration (confirmatio), and a conclusion (peroratio). ADD BIBLIO Somewhat surprisingly, Judah's speech has exactly the structure prescribed by

\footnotetext{
${ }^{17}$ Another possible approach would be to contest the competence of the court, but again this would have been a self-defeating strategy in the case at issue.
} 
the classical authors. The latter two parts of his speech are distinctly marked in Hebrew by means of the expression "and now".

- In verse 18 Judah opens his speech and flatters his interlocutor: "You are like Pharaoh"- a captatio benevolentiae exactly the way it is recommended in classical rhetoric.

- In verses 19 to 29 , Judah reminds the minister of the earlier visit and tells him what happened in Canaan between the two visits. This is a typical narratio.

- In verses 30-32, Judah argues, on the basis of the reported facts, that it would be right to let Benjamin go, and to take him instead as a slave.

- Finally, in verses 33 and 34, Judah wraps up his speech. In classical rhetoric it is recommended to devote part of the conclusion to a recapitulation of the facts (peroratio in rebus) and part to an appeal to the feelings of the audience (peroratio in affectibus). And that is what Judah does: first he repeats his central demand: "Now therefore, I pray, let me stay instead of the boy as a slave to my lord; and let the boy go home with his brothers" (v. 33). Then he ends his speech with an impassioned appeal: "How shall I go up to my father, if the boy is not with me? lest peradventure I couldn't bear to see my father's pain!” (v. 34).

Neither Judah, nor the author of the book of Genesis could have known the classical theory of rhetoric. Although biblical texts are hard to date, there are good reasons to submit that the Joseph story came into being during the monarchic period, hundreds of years before Aristotle. ADD BIBLIO The agreement of Judah's speech with the classical scheme merely indicates that human speech has universal characteristics.

\section{Elocutio}

The style of Judah's speech, too, conforms to the demands of classical rhetoric: it is precise, clear, and adorned. The precision is expressed not only in the right choice of words and the correct grammar of the sentences, but also in the courtly style by which Judah addresses the Egyptian: "Please allow your servant to speak a word with you, mu lord"- Judah knows how to speak to important people. In the narratio, where Judah recounts the earlier visit and the intermezzo in Canaan, his diction is very factual. In the argumentative section, the confirmatio, he uses a more figurative style: “my father's soul is bound up with his son's soul" (v. 30); "your servants will bring down the grey hair of your servant our father in sorrow to the grave" (v. 31). 
Judah's speech conforms to the classical teaching on rhetoric to a surprising extent. This confirms our earlier postulate about the usefulness of classical rhetoric in the study of persuasive speech in the Bible.

\section{Original features of biblical rhetoric}

Classical theory cannot account for all features of Judah's speech, however. Some of its persuasive techniques find no parallel in Greek or Latin texts. Three characteristics of Judah's speech will be pointed out that are more or less alien to classical rhetoric, but typical of biblical oratory.

\section{Eloquent reticence}

In light of the importance of clarity in classical rhetoric, one can only be struck by the fact that Judah omits a number of important points from his speech. Perhaps it is natural that he should keep silent about things that couldn't contribute to his persuasive strategy. Judah skips entirely over the crime of which Benjamin is accused. He has decided, it seems, that there is no way to make the crime appear less grievous, and therefore prefers not to mention it at all.

In keeping with his goal, which is to arouse the minister's compassion, Judah avoids to underscore any negative event that happened between the minister and the brothers. Thus he glosses over the hostile atmosphere of the first visit: he mentions neither the accusation of spying, nor the imprisonment of Simeon. Judah also skips over the long period between the two visits. He says: "When we came up to your servant my father, we told him the words of my lord. Our father said, "Go again, buy us a little food" (v. 24-25) - as if the second visit followed immediately upon the first. In reality, a lot of time must have gone by between the two visits. The brothers only return to Egypt when all the food they brought home is consumed. The omission of these elements from the speech is daring, because the minister knows everything that happened full well. Nevertheless, one understands why Judah omitted these elements. One might even admire the astute way Judah avoids all matters that could only harm his persuasive strategy.

It is much more difficult to understand why Judah omits an issue that appears to be central to his speech. The goal of the plea is to awaken the minister's compassion so that he will agree to let Benjamin go and take Judah in his place. If this is so, it is surprising that the entire speech does not contain any explicit appeal to the minister's compassion. All terms connected to this notion: the nouns compassion, mercy, pity, grace, goodwill, as well as their cognate verbs, are completely lacking. On this point, it is interesting to compare the biblical 
version of the speech with its re-rewriting in Flavius Josephus' Antiquities. Josephus' version of the speech is longer than the biblical one, and it contains a number of additional arguments. Nevertheless, the essential nature of Judah's plea is well preserved in the later paraphrase. Yet, Josephus adds several explicit appeals to the compassion of the minister: "There remains some hope for us ... from your goodness, says Judah to the minister, which promises us a deliverance out of our present danger. ... bestow on us your pardon... have regard to our father, and take pity of his old age... by forgiving our brother ... you will preserve us all" (Ant. II 140-154). It seems that Josephus correctly understood that Judah's entire speech was based on a plea for mercy. Moreover, being well versed in classical rhetoric, he felt that an explicit appeal was lacking, and decided to supply it in his rewritten version. All this underscores what is lacking in the biblical version of the speech: why does Judah's speech in Genesis not contain any explicit reference to the good heart of the minister, to the clemency the brothers are hoping for, to the pity one should show towards a father?

Judah's silence on these points does not indicate a lack of eloquence. On the contrary, it may reflect a rather sophisticated aspect of Judah's rhetorical strategy. Indeed, some requests are better expressed indirectly. Remember that Judah's plea has little basis in reality: why should an Egyptian judge feel compassion toward a Hebrew thief? If Judah had articulated his claim, the minister might have realized that the plea for mercy was out of place. It is preferable for Judah to do all that is in his power to move the Egyptian man to compassion, without revealing what he wants to achieve. This is exactly what Judah does: he repeats over and over again that Benjamin is young, that his father is old, that breaking the connection between them will result in catastrophe, of the kind which already befell the family before. It was unnecessary to add the explicit appeal: "Please, have pity upon us!"

There is yet another side to Judah's omission. As is well known people more easily embrace an idea they themselves discover than an idea suggested to them by someone else. If Judah had proposed to the minister to pardon Benjamin and to let him go, the minister would have adopted an objective attitude towards the proposal. But if, instead, Judah succeeds in engendering in the minister's heart, so to speak, the idea that it would be right not to judge the Hebrew boy according to the strictest standards, this idea will be much more attractive and acceptable to him. In general linguistics, a "cooperative principle" has been identified: when humans converse, they cannot possibly say all they want to express; they therefore rely on their interlocutors to complement what is lacking. Judah exploits the cooperative principle in order to realize his rhetorical objective. 
This is not something peculiar to Judah's speech. It is a feature of biblical rhetoric generally. In many other instances, biblical heroes omit important points from their speeches, or even the central request on which their entire speech is oriented. Above the example of the captain of fifty was referred to, who does not explicitly request Elijah to come with him to the King - although that is what he seeks to obtain. There are many other examples:

a) David sends messengers to the citizens of Yabesh in Gilead to bless them for the charity they have done to King Saul by burying his body (2 Sam 2:5-7). He mentions incidentally that Judah has anointed him king. He does not add that he is ready to become the king of the northern tribes as well, although that is clearly the main point he wants to get across in the speech.

b) At the instigation of Nathan, Bathsheba comes to see David in his old age. She reminds David of an oath he swore to make Solomon his successor, and adds that the eyes of all Israel are upon David (1 Kgs 1:17-21). But she doesn't express her explicit request that David should install Solomon on the throne.

c) Jotham, in his long and complex speech addressed to the citizens of Shechem after they have killed his brothers never once tells them explicitly: what you have done is wrong.

In all these passages it is possible to find reasons for the omission of the central claim. Some things don't need to be stated explicitly, others are better left unsaid. At the same time, in all these passages the principle we have discovered is also at work: by omitting a central issue from the speech, the orator invites the audience to cooperate in the process of persuasion. The speaker passes in silence over an important matter, relying as it were on the capacity of the audience to supply what is missing, and thus to convince themselves of the central point of the speech.

\section{Introducing a "significant third"}

Classical rhetoric recommends the categories of ethos and pathos: the orator must project a positive image of him or herself, and he or she must take into account the feelings of the audience. Biblical rhetoric tends to mix these two categories together: persuasion is based not on the presentation of the orator on the one hand and the sensitivities of the audience, on the other hand, but on the relationship between the two parties. This difference is a gradual one, not an absolute one. It appears to be connected to the difference between the institutional background of Greco-Roman rhetoric and the more familial background of many biblical speeches. In Judah's speech, the relational aspect is prominent. Above it was argued that 
Judah finds his best arguments on the level of pathos. But in fact it would be more correct to observe that Judah first of all seeks to develop some sort of affinity with the Egyptian minister. As an impartial judge, he will perhaps not be inclined to show mercy to Benjamin. But as one who is close to the brothers and their family, he may do so.

The means Judah choses to arrive at this result is surprising. In a defence of his brother who is accused by an Egyptian official, Judah introduces a third party who at first sight has nothing to do with the issue under discussion. Judah doesn't speak about the crime at all, as we saw, and he speaks rather little about the solution he proposes. But he does speak a lot about his father: his old age, the troubles that have befallen him, his love for his "two sons", and the catastrophe that will happen if Benjamin doesn't come home. This insistence on the father has no legal value: the fact that Benjamin has a father who loves him could in no way justify his crime.

Of course, Judah may really be worried about his father. He has promised to his father that Benjamin would return, and can hardly go back home without his brother. However, the mention of the father does not simply reflect Judah's worries. Instead, it serves his persuasive strategy. Judah introduces the father into the speech because he thinks it will help convince the minister to free Benjamin. By means of a poignant story about a father and his sons, Judah suggests that among brothers and family members, it is right to be forbearing and lenient toward one another. Judah tells the minister: "Our father said to us: 'You know that my wife bore me two sons' - he said that to us, ten sons of a different wife, but still we love him and worry about him. That is the way one should behave toward one's family." By telling the story, Judah draws the minister into the family circle. It is almost as if Judah wishes to suggest to the minister that he too is a member of the family. By introducing a "third party" Judah tries to develop a personal relationship with a stranger. The strategy is not based on logic. But we can feel its strength. ${ }^{18}$

The introduction of a "third party" to enhance persuasion characterizes not only Judah's speech. It is a technique we encounter in many other biblical speeches, particularly in cases where the position of the orator is weak (as in the case of Judah):

a) On two occasions, David, who has hid in the desert, speaks to King Saul who is pursuing him, and tries to persuade him to leave him alone. On both occasions, David

\footnotetext{
${ }^{18}$ The impact of the language of kinship is increased by the ironic fact that Judah really is speaking to his brother. The author of the Joseph story is working on different levels at the same time. In the present study, the discussion is limited to the viewpoint of Judah, who attempts to sway an Egyptian minister to alter his verdict.
} 
introduces God into his speech. His claim is that because both of them, Saul and David, have a relationship to God, it would be right for Saul to stop chasing him.

b) An excellent example, although somewhat peculiar, is that of Abigail's speech. David is on his way, with 400 men, to wipe out Nabal and all his family. Abigail meets him halfway and tries to stop him. Surprisingly, she does so by presenting herself as the main culprit: "In me, O lord, is the iniquity! ... I, your handmaid, saw not the young men of my lord, whom you sent ... Please forgive the transgression of your handmaid" (1 Sam 25:24-28). The role she attributes to herself is particularly farfetched: why should she be guilty of not seeing David's men? And what could she have done if she had seen them? But the way she introduces herself as a "third party" standing between David and Nabal is highly effective rhetorically. It is hard for David not to pardon this beautiful and intelligent woman who stands before him and implores his mercy. It is difficult also to refuse the gifts she is bringing. But once David has accepted her claims regarding herself, he is practically forced to pardon her husband also.

\section{Rhetoric and truth}

A final aspect of Judah's speech remains to be mentioned, namely its stance in regard to the truth. In the classical world, the relation between rhetoric and truth is problematic. Neither the central claim, nor the arguments need to be true, they only need to be persuasive. If lies are more convincing than the truth, it is better to lie. Consequently Plato condemned rhetoric. To Plato, the whole classical theory of rhetoric was completely superfluous. All that was needed was that intelligent people should speak the truth with one another. In the Bible too there is a certain tension between rhetoric and the truth. The biblical authors know full well that lies are often sweeter than the truth, and that flattery is a good way to seduce one's audience. At the same time, there is a strong awareness in the biblical literature of the fact that God, who is just and all-knowing, watches over the truth. This dynamic is at work also in Judah's speech.

On the face of it, Judah's attitude to the truth seems to be rather liberal. When he comes to tell of what happened during the first visit, and in the land of Canaan, he weaves a tale that is to a large extent untrue. He uses a factual style, as was mentioned above, but this masks a largely fictional content. We know, from reading chapter 42 , that the first visit was a very unpleasant experience for the brothers. Immediately after their arrival in Egypt, they are accused of spying, and thrown into jail for three days. As was remarked above, Judah omits 
all reference to this earlier hostility. But he doesn't only lie by omission! He positively tells a story of a pleasant encounter:

— v. 19 "My lord asked his servants, saying, do you have a father, or a brother?" Judah presents the first meeting of the brothers and the minister as a polite conversation. The minister was curious about the family background of the brothers, and they were happy to answer his questions. In fact, however, the brothers only revealed that they had a father and a brother in order prove that they weren't spies.

- V. 21 "And you said to your servants, Bring him down unto me, that I may set my eye upon him" Judah suggests that the minister wanted to see Benjamin in order to treat him well. In chapter 42, however, the minister demands that the brothers bring Benjamin to him in order to verify that they were not lying.

- V. 22 "And we said to you, The boy cannot leave his father: for if he should leave his father, he would die" This affirmation is very important to Judah's claims. It allows him to suggest that the minister is in some indirect way responsible for all that happened later. It is if he's saying: We warned you, but you wouldn't listen! In chapter 42 , however, this sentence is lacking. In fact, it is very hard to imagine that the brothers said anything like this. Accused of being spies, they were not in a position to bargain. ${ }^{19}$

In the second part of the narratio, Judah is more faithful to the facts. Still, even here, there is a gap between what he says and what really happened:

- V. 27-28 "Your servant, my father, said to us, 'You know that my wife bore me two sons: and the one went out from me, and I said, "Surely he is torn in pieces;" and I haven't seen him since.' After "My father said" one expects a precise quotation of Jacob's words. It is unlikely, however, that Jacob ever said anything like this to the sons of Leah. This is not a real quotation, but a kind of pseudo-quotation, comparable to the verse from the Psalms: "The fool says in his heart: "There is no God"' (Ps 53:2). In classical rhetoric it is recommended to insert into the narratio the seeds of proof (semina probationum). This is precisely what Judah does: he tells the facts in such a way that the minister will be led to accept his claim. In doing so, however, he perverts the factual truth to a certain extent. This does not mean that Judah is generally untruthful. On the contrary, his whole speech is in fact oriented toward the truth - not the factual truth, but a truth that

\footnotetext{
${ }^{19}$ Pace M. A. O'Brien, 'The Contribution of Judah's Speech, Genesis 44: 18-34, to the Characterization of Joseph', CBQ 59 (1997), 434-440.
} 
transcends the facts. Once, the brothers lied in order to eliminate a younger brother who was especially beloved of their father. Today, Judah is prepared to sacrifice himself on behalf of another younger brother, equally beloved of their father. Judah has set aside the ways of lying and trickery. With age, he has learnt that falseness tends to fall back on the one who brings it into the world. He wants the truth, now. All the subtlety of his speech serves this truth: Benjamin must be allowed to go home to his father, because of the special love Jacob has for him. He, Judah, is ready to pay for his earlier sins and accept a life in slavery.

In classical rhetoric, a good speech is a persuasive speech. In the biblical world, there is no merit in persuasion as such. In the case of the speech we are studying, this aspect is very clear in light of the narrative framework. All Judah's rhetorical effort in the end serves no useful purpose. Or rather, it serves a purpose, but not one Judah could have been aware of. The minister is not persuaded in regard to Benjamin - he doesn't need to be, he knows full well that Benjamin is innocent. But Joseph is persuaded in regard to Judah.

The dialectics of persuasion and truth comes to expression in many other speeches in the Bible. The best illustration of it can be found in the book of Job. Job and his friends debate on the question: is Job righteous, or does he deserve his sufferings? The speeches are beautiful and well constructed. But nobody convinces anybody else of anything. In the end, God appears on the scene and reveals that Job was right and the friends were wrong.

\section{Conclusion}

Judah's speech can be read as a test case of rhetorical discourse in the Bible. Rhetoric is speech in action, its objective is to operate a change in the real world.

Classical rhetoric can help in approaching the biblical speeches. It shows the way to a correct analysis. In the end, however, many characteristics of biblical rhetoric diverge from what is taught by Aristotle or Quintilian. Perhaps it is fair to say that the most typical features of biblical rhetoric are alien to the classical theory.

A comparison of Judah's speech with other persuasive speeches shows that the biblical authors had their own rhetoric. This field of study has not attracted much attention so far. An important field of biblical studies remains yet to be explored. 